
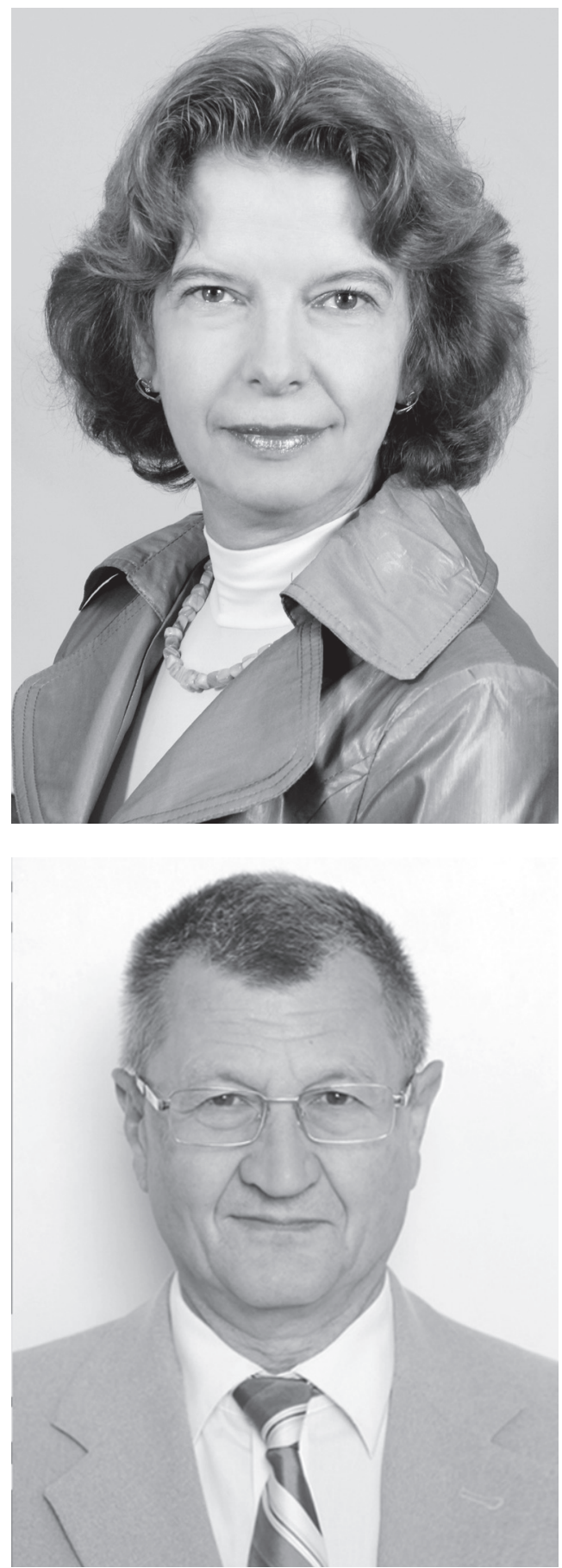

Лахижа Николай Иванович, бличного управления и администрирования, Институт подготовки кадров государ- 
ственной службы занятости Украины, 03038, г. Киев, ул. Нововокзальная, 17, тел.: (096) 5521789 ,e-mail: lahisha@ukr.net

\title{
PUBLIC-PRIVATE PARTNERSHIP AS A SUSTAINABLE DEVELOPMENT FACTOR: AN ARCHETYPAL ANALYSIS
}

\begin{abstract}
An archetype analysis of the problems of public-private partnership (PPP) functioning and its role in ensuring sustainable development has been carried out. The necessity of taking into account transformational changes which resulted not only in changing the political system and forms of ownership and the transition to democracy and market economy, but also combined with the change in the mentality of the population, was emphasized. There is a need to rethink the role of the state in public relations. The partnership is considered, on the one hand, as a goal and a task of sustainable development, which demonstrates a change in the paradigm of solving problems from individualized to unified, network, and on the other hand, as a factor of its providing. The significant role of PPP in ensuring sustainable development has been proved. The dependence of the level of development of PPP on the development of state and civil society, the level of awareness of public and private partners of their social responsibility is indicated. It is noted that the concept of "public-private partnership" is broader and more consistent with the tasks of stimulating sustainable development than "state-private partnership". It is concluded that national mentality, social and cultural norms in the country can significantly influence the perception of the idea of the PPP, and therefore these projects should be adapted to the local context. The barriers for implementation of PPP are analyzed, among which the following are highlighted: imperfection of administrative processes, insufficient legal and regulatory framework with frequent changes in the legislation and regulations, concentration of attention on procedural issues with underestimation of the innovative and investment potential of the PPP, and in particular, its role in the formation of new public relations and civil society. An archetypal analysis has allowed substantiating the need for increased participation of the third sector in the processes, ensuring their openness and transparency. It is about overcoming "collectively unconscious" in favor of conscious collective action in support of sustainable development.
\end{abstract}

Keywords: sustainable development, public-private partnership, modernization, archetype, mentality, implementation barriers.

\section{ПУБЛІЧНО-ПРИВАТНЕ ПАРТНЕРСТВО ЯК ФАКТОР ЗАБЕЗПЕЧЕННЯ СТАЛОГО РОЗВИТКУ: АРХЕТИПНИЙ АНАЛІЗ}

Анотація. Здійснено архетипний аналіз проблем функціонування публічно-приватного партнерства (ППП) та його ролі в забезпеченні сталого роз- 
витку. Наголошено на необхідності врахування трансформаційних змін, які призвели не лише до зміни політичного ладу та форм власності і переходу до демократії та ринкової економіки, а й супроводжувалися зміною менталітету населення. Відзначається необхідність переосмислення ролі держави у суспільних відносинах. Партнерство розглядається, з одного боку, як мета і завдання сталого розвитку, що демонструє зміну парадигми вирішення проблем з індивідуалізованої на об'єднавчу, мережну, а з іншого - як фактор його забезпечення. Доведено значну роль ППП у забезпеченні сталого розвитку. Вказується на залежність рівня розвитку ППП від розвитку держави та громадянського суспільства, рівня усвідомлення публічним та приватним партнерами своєї відповідальності перед суспільством. Відзначено, що поняття “публічно-приватне партнерство" ширше і більше відповідає завданням стимулювання сталого розвитку, ніж “державно-приватне партнерство”. Зроблено висновок, що національний менталітет, соціальні та культурні норми в країні можуть істотно впливати на сприйняття ідеї ППП, тому ці проекти мають бути пристосовані до місцевого контексту. Проаналізовано бар’єри для впровадження ППП, серед яких виділено: недосконалість управлінських процесів, недостатню нормативно-правову базу з частими змінами законодавства та правил регулювання, концентрацією уваги на процедурних питаннях при недооцінці інноваційного та інвестиційного потенціалу ППП, а особливо - його ролі у формуванні нових суспільних відносин та громадянського суспільства. Архетипний аналіз дозволив обгрунтувати необхідність посилення участі в процесах ППП третього сектору, забезпечення їх відкритості та прозорості. Йдеться про подолання “колективно несвідомого” на користь свідомих колективних дій на підтримку сталого розвитку.

Ключові слова: сталий розвиток, публічно-приватне партнерство, модернізація, архетип, менталітет, бар'єри впровадження.

\section{ПУБЛИЧНО-ЧАСТНОЕ ПАРТНЕРСТВО КАК ФАКТОР ОБЕСПЕЧЕНИЯ УСТОЙЧИВОГО РАЗВИТИЯ: АРХИТИПИЧЕСКИЙ АНАЛИЗ}

Аннотация. Осуществлен архетипический анализ проблем функционирования публично-частного партнерства (ПЧП) и его роли в обеспечении устойчивого развития. Отмечена необходимость учета трансформационных изменений, которые привели не только к изменению политического строя и форм собственности и перехода к демократии и рыночной экономике, но и сопровождались изменением менталитета населения. Отмечается необходимость переосмысления роли государства в общественных отношениях. Партнерство рассматривается, с одной стороны, как цель и задачи устойчивого развития, что демонстрирует изменение парадигмы решения проблем с индивидуализированной на объединительную, сетевую, а с другой - как фактор его обеспечения. Доказано значительную роль ПЧП в обеспечении устойчивого развития. Указывается на зависимость уровня развития ПЧП от развития государства и гражданского общества, уровня осознания пуб- 
личным и частным партнерами своей ответственности перед обществом. Отмечено, что понятие “публично-частное партнерство" шире и больше соответствует задачам стимулирования устойчивого развития, чем "государственно-частное партнерство”. Сделан вывод, что национальный менталитет, социальные и культурные нормы в стране могут существенно влиять на восприятие идеи ПЧП, поэтому эти проекты должны быть приспособлены к местному контексту. Проанализированы барьеры для внедрения ПЧП, среди которых выделены: несовершенство управленческих процессов, недостаточную нормативно-правовую базу с частыми изменениями законодательства и правил регулирования, концентрацию внимания на процедурных вопросах при недооценке инновационного и инвестиционного потенциала ПЧП, а особенно - его роли в формировании новых общественных отношений и гражданского общества. Архетипический анализ позволил обосновать необходимость усиления участия в процессах ПЧП третьего сектора, обеспечения их открытости и прозрачности. Речь идет о преодолении “коллективно бессознательного” в пользу сознательных коллективных действий в поддержку устойчивого развития.

Ключевые слова: устойчивое развитие, публично-частное партнерство, модернизация, архетип, менталитет, барьеры внедрения.

Formulation of the problem. The concept of sustainable development is the most promising paradigm of functioning of the modern society, which, provided consistent, comprehensive and effective implementation, will allow to resolve the contradictions of the civilizational evolution, minimize the threats to the existence of humanity and provide a permanent process for improving the situation of every person. The very person, its comprehensive development, welfare, health, and not only the quantitative indicators of the economic growth, is the purpose of the embodiment of this concept. Its essence that consists in the necessity of harmonious combination of three components of development - economic, social and environmental, - are multifaceted reflecting synonymous terms that are translations of the English word sustainable in other languages: stable, measured, balanced, responsible, viable, supported, long, etc.

In addition, the rate of development is not always carried out at the most important level in order to implement it, because investments in the new infrastructure in the world in the coming years, according to various estimates, should be from 3,5 to 5 trillion dollars annually. It is clear that, first of all, the states are responsible for achieving the goals of sustainable development. But, given the objective limitations of the public financial resources, the question is how to attract private capital to address these challenges. Among other ways, the mechanism of public-private partnership (PPP) that is already sufficiently institutionalized and practically tested is capable of significantly reducing the gap between the resource 
requirements and the possibilities for their accumulation. This requires the deepening of the research on the nature and content of the PPP, the conditions for its use, and also the institutional, mental and other obstacles to its effective functioning.

Analysis of the recent research and publications. The problem of the development of state-private (and now more and more - public-private) partnership has been in the field of domestic scientists, representatives of both economic science and state administration science for more than ten years. They have developed a significant multidimensional theoretical work that has only been embodied in recent years in a number of fundamental monographs [1-3]. At the same time, the scientists are actively studying the issues of interconnectedness of the PPP and ensuring sustainable development. Among recent studies it is worth noting the work of such authors as V. Gusev, A. Zhukovska, N. Ilchenko, I. Kulchiy, D. Lavrentiy, S. Maystro, O. Makar, B. Pomogaybo [4-11] and others. These problems are discussed in the format of scientific and practical conferences [12; 13]. Important for our research are the publications of foreign scientists, in particular [14-16].

However, it is well-known that public-private partnerships have not come up with the modern conditions of development where it is most needed - in developing countries and in the countries with emerging markets. In order to improve this situation, it is expedient to apply new approaches and methods for analyzing PPP mechanisms. An analysis of the PPP from the point of view of archetype has already begun as domestic (S. Doroshenko, I. Zapatrina, S. Yushyn) and as well foreign authors (M. Kanya). In our view, the archetype is precisely a promising approach that will highlight the previously unresolved problem aspects of the functioning of the PPP to ensure sustainable development.

The purpose of the article is to determine the role of PPP as an effective tool for the implementation of sustainable development, to find out the underlying factors of the influence on its development, the reasons for the introduction of the barriers and the theoretical generalization of the possibilities of an archetypical approach in this area of social relations.

Presentation of the main material. The end of the $20^{\text {th }}$ century in the global dimension was characterized by complex and ambiguous transformations. On the one hand, new states arose in Europe, accompanied by processes of national renaissance, growing attention to national characteristics, and the desire, through an analysis of the national mentality, to comprehend the events of our time. On the other hand, under the influence of globalization there was a blurring of the national peculiarities, the world's perception of people was rapidly changing, new values and beliefs were formed. For example, for the countries of Central and Eastern Europe, the common denominators in the period of post-communist transformation were the abandonment of totalitarian mentality, "Europeanization" that consists in the adoption of common standards for life and development for the countries of the European Union. Accordingly, the scientists and politicians have grown up in search 
of answers to questions of civilization membership and the possibility of using existing experience of the successful functioning of the developed countries [17]. An analysis of "self", as defined by C. Jung, was an actual analysis of the archetype of the integrity of the individual, uniting the conscious and the unconscious, mutually complementing each other. The subject of analysis, including in terms of archetype, became such categories as "public", "private", "partnership".

It is important to note that it was during this period that active searches for new forms of public administration took place that would take into account both the interests of the state and the interests of the society, and placed the focus of attention on the person. Consequently, inevitably it had to increase and indeed it has increased - the attention to a person as a reasonable political and social being. There was a need to rethink the role of the state and society, to find out the underlying foundations of such social phenomena as partnership, cooperation, interests, conflicts, standards, values, etc. Increased attention has been paid to the interdependence of the concerns of the whole world - environmental, economic, social, and cultural, that are united in the paradigm of sustainable development.

Recall that in the early 1970's there was a conviction that the problems of the development and the environment should be considered in close relationship, but the very term "sustainable development" and its definition appeared in Brundtland's report "Our Common Future" only fifteen years later, in 1987. Sustainable development ideas were formally proclaimed in 1992 at the International Conference on Environment and Development in Rio de Janeiro, where the need for a harmonious combination of two goals was set: to provide a high-quality environment and meet the needs of people at the expense of stable, long-term economic development. In 2002 a new organizational form for the implementation of this concept was proposed - the so-called partnerships for sustainable development that emphasized the importance of joining forces, joint actions both globally and nationally.

In 2015 the United Nations adopted a sustainable development based on its program of activities by 2030 and identified the seventeen Sustainable Development Goals (SDG) that were endorsed by all UN member states. These goals are specified in 169 tasks and reflect such spheres of action as people, planet, prosperity, peace and partnership.

Our country has been working hard to adapt the global SDG to the national specificities, which resulted in the National Report "Sustainable Development Goals: Ukraine" [18] that contains 17 goals, 86 tasks and 172 indicators. In this, one of the goals is directly defined as a partnership for sustainable development and includes tasks 17,3 - to develop partnership relations between the state and business to achieve the Sustainable Development Goals.

The analysis of the content of the above documents leads to the conclusion that they have a partnership, acting on the one hand as a goal and objectives of sustainable development, demonstrating a change in the paradigm of solving individualized problems, divided into unifying, collectivist, 
network, and on the other - as a factor in its provision. In particular, the global partnerships serve as guarantors of peace preservation and contribute to overcoming poverty and inequality in the world. And the PPP is in modern terms a method that allows "to build a sustainable infrastructure, to promote inclusive and sustainable industrialization and to promote innovation" (ninth global goal). However, since the content of the goals of sustainable development "intersects", the formation of a quality and affordable infrastructure to support economic development and human well-being will simultaneously mean progress, in particular, in creating new jobs, providing energy from renewable sources, clean water, hygienic living conditions, high-quality health care and education, etc. In turn, the PPP infrastructure project, for example, in the water supply sector, corresponding to goal 6 ("clean water and proper sanitary conditions"), will contribute to reducing the mortality and disease from the use of contaminated water (task 3,9). You can still cite a large number of similar examples.

Consequently, the role of the publicprivate partnership in ensuring sustainable development can be really significant, but not always its potential is effectively implemented in practice. In particular, small-scale and low rates of implementation of PPP in almost all post-communist countries of Europe and Central Asia (ECA) indicate that there are certain deterrent factors that we believe are generated not only by the national institutional and mental characteristics, but also by the general features of modernization processes occurring in these states.
It is worth noting that these countries are characterized by a high level of legal regulation of PPP, since $95 \%$ of them have adopted special laws on public-private (or state-private) partnership. However, they are somewhat inferior to the highly developed OECD countries regarding the quality of the preparation of PPP projects and the procedures for identifying a private partner: while the assessments of these processes in these countries are 65 and 79 points (out of 100), for ECA countries they make 50 and 67 points, respectively [19, p. 37, 46]. As regards the management of the project implementation, post-communist ECA countries with 52 points fall not only from the highly developed OECD countries (60 points), but also from the countries of Latin America and the Caribbean (63 points) and the Middle East and North Africa (54 points). But especially they are lagging behind the leaders (72 points) regarding the availability of proposals for the PPP coming not from the public, but from the private sector (53 points) [19, p. 56, 64].

Over the last decade, the share of ECA post-communist states in total investment in PPP projects in developing countries and emerging markets has declined from $30 \%$ to $5 \%$ [20, p. 7]. The situation in Ukraine is described in the above-mentioned National Report that states that the pace of practical application of the PPP is unsatisfactory. One of the main reasons for this is the lack of confidence in the state as a business partner due to the continuing instability of the public finances, the volatility of legislation, and the high level of corruption [18, p. 125126]. 
Recall that the very question of the introduction and development of PPP in post-communist countries could only arise in the process of modernization of all the spheres of the social relations, the formation of a full-fledged market economy, the organization and improvement of the mechanisms of public administration. Post-communist transformation is a process of substantial, profound social change, that, moreover, began suddenly, without a preliminary calculation of possible losses, without a prepared economic and political elite, without historical experience of overcoming the communist social heritage. The crisis of the social consciousness appears as the root cause and source of the institutional changes [21, p. 6].

Analyzing the PPP in this context, it is methodologically advisable to note the need for an interdisciplinary approach rather than a mechanical combination of the results of various scientific fields. Our research of the phenomenon of PPP in the post-communist states shows the aspiration of both scientists and practitioners to study and implement existing experience, an attempt to use achievements that have already shown themselves positively in other countries. In this case, the analysis of the mental factors is often left aside, which in practice leads to attempts to introduce others from the point of view of archetype practice to a particular country.

The awareness of the essence of post-communist transformations in the conditions of globalization and the objectivity of change of consciousness allows to re-evaluate the public-private partnership. We analyzed the legal acts and practices of scientists from a num- ber of post-communist states (Belarus, Bulgaria, Kazakhstan, Poland, Russia, Ukraine) on this issue, relevant English-language publications. First of all, it should be noted that only Bulgaria and Poland use the term "public-private partnership", which has become widespread throughout the world from the countries listed. We support the viewpoint of those domestic scientists who note that PPP in terms of content, form and range of partners differs from the concept of state-private partnership (SPP) [4, p. 68]. In the election of such a term reflects the mental perception of the state as the dominant entity in relations with other actors (business and civil society) [8, p. 85]. But experience, in particular, Poland demonstrates a significant role in PPP and local selfgovernment bodies that can not be covered by the term "state". Consequently, in this case, there is a classic version of conservative thinking and an orientation towards the established terminology of the normative legal acts.

In addition, both PPP and SPP, in our opinion, are traditionally considered in the narrow sense - as agreements, projects of cooperation between the public and private sectors in the legislatively defined framework (projects, concessions, joint ventures). However, in today's conditions there is a tendency that is characterized as the development of "state-private-civil partnership" [6, p. 34], "joint responsibility of the state, community and business" $[9$, p. 246], etc. Therefore, we believe that the term "PPP" is broader, covering the public sector, local government, the private sector and civil society. After all, the traditional perception of the SPP as the sole economic and legal mechanism 
for cooperation between the public authorities and business in the field of infrastructure development is not sufficient to focus on the environmental and social goals advanced by the concept of sustainable development. At the same time, the civil society actors do not act as a party to the agreement, but create a network of support, dissemination of information, training, analytical support, and others.

Consequently, we can conclude that, in the broadest sense, the PPP should be perceived as an integral part of the development of the principles of a democratic social state and of ensuring sustainable development that goes back to the theory of social partnership. In the narrow sense PPP is an alternative to privatization, an instrument for creating infrastructure and economic growth, a social responsibility of the private sector, the emergence of a new public administration, and the provision of quality public services.

It is worth to understand that the place of PPP in the public relations and its impact on sustainable development is determined by its advantages and disadvantages that are sufficiently comprehensively analyzed in the scientific literature $[1 ; 3 ; 15]$, as well as the presence of barriers to the implementation and operation. Thus, the Polish scientist M. Tkachuk believes that each of the three sectors (public administration, business and non-governmental sector) in the post-communist countries is different in its specificity, which holds back the development of partnership and, in our opinion, has an archetypal nature. For the public sector it is the belief in omnipotence, bureaucracy and schematism in actions, wasteful- ness or, conversely, excessive savings, the propensity to pressure from the social or professional groups, the subordination to political interests, opportunism, inconsistency in actions, etc. The private sector can be characterized by a desire for profit at all costs, selfishness, a tendency for self-promotion, the desire to take advantage of tax privileges, etc. The public sector is characterized by, in particular, the lack of skilled personnel, financial ignorance, lack of consolidation and responsibility, dispersion and inconsistency of actions, etc. [22, p. 321-323].

The analysis allowed to identify the barriers to the implementation of the PPP, which, in particular, derives from the above features. First of all, this is an inadequate level of communication between the stakeholders and the general public. There is a clear distrust, the desire of the public sector to show its decisive role, ignoring the interests of the partners, etc., which is a manifestation of past stereotypes. At the same time, it must be taken into account today that any mechanism aimed at providing public goods, but not subject to private control, can not be successful without broad consultation, exchange of views, consideration of different interests, public support and admissibility of its conditions for all the stakeholders. Summarizing, we can say that it is necessary to create an atmosphere of trust the main role in what should play the state. Without this inevitably there is a conflict of interest that can be considered the next obstacle to the development of the PPP.

The national mentality, social and cultural norms in the country can significantly influence the perception of 
people of the idea of public-private partnership and their relation to its implementation. Organizationally, the PPP relates to a relatively small number of public and private partners and remains a mysterious phenomenon for most citizens, which is not only characteristic of the Ukrainian mentality that is embodied in the saying "my hut is on the edge". Therefore, PPP projects should be adapted to the local context. It is necessary to remember that it is concrete people, not abstract "public" and "private" partners who are involved in the organization of these processes. In addition, they operate in a certain mental environment that can be favourable, neutral or even hostile in relation to the attempt to attract business to the provision of public services, which is considered the prerogative of the state. In particular, in the post-communist countries, especially in the former republics of the USSR, the paternalistic idea of the state and its social functions is not yet fully absorbed. Accordingly, it is from the state and local governments that it is expected to provide affordable, inexpensive, and even better free services, and not only control over their provision. This idea is the opposite of the PPP ideology that does not focus on who the provider is, but focuses on the need to provide people with the best possible access to high-quality public services. The main criterion for the effectiveness of such projects is recognized as "value for money", that is, the ratio of the value received by the society and the cost of its provision. At the same time, the value can be understood not only the volume of services, but also the fact of their availability (which would not be without the participation of a private partner), the possibility of receiving services at an earlier date, ensuring higher standards of service provision, etc.

A significant barrier to the implementation of the PPP is the inadequacy of the requirements of the time (weakness) of the management processes, which, in the broadest sense, include an imperfect incentive (engagement) policy, a lack of legal and regulatory framework, with frequent changes in legislation and regulation and, directly, project management mistakes. The experience of Ukraine, Bulgaria, Poland, and other post-communist countries shows the complexity of developing a regulatory framework in the field of PPP, which, on the one hand, would take into account world the (European) standards, and on the other hand, was adequate to the national specificity and state of the economy. This is largely due to the targeting of the existing legislation to strengthen the public ownership of the development of various types of infrastructure and its inadequacy to the needs of the private sector; focusing on procedural issues in underestimating the innovative and investment potential of the PPP, and, in particular, its role in shaping new social relations and civil society, the important principles of which are pluralism, rule of law, mutual responsibility of the state and persons, equality of law for all, etc. The ignorance of the psychological factors and mentality of the business representatives was one of the main reasons for the ineffectiveness of the law on public-private partnership that was adopted in Poland in 2005 and had to be replaced in 2008 by new ones. 
Regarding the deficiencies in the management of PPP that hinder its implementation, it is worth noting the dominance of chaos that manifests itself in the lack of correctness of the procedure for identifying and selecting the projects where private participation is appropriate; attempts at the same time to achieve several conflicting project objectives (financial, macroeconomic, social, environmental, etc.); irrational distribution of responsibilities and risks between the partners during the project implementation, which in one way or another will increase the amount of the public expenditure; lack of clear criteria and indicators of the effectiveness of the project implementation, which complicates the monitoring of achievement of the objectives, etc.

It is important that the above-mentioned barriers are recognized by the participants in the PPP process - the representatives of the public and private sectors, as evidenced in particular by the results of expert surveys conducted in Poland at two scientific and practical conferences in 2007 and 2011 [12]. The first positions were taken by such barriers as low level of consciousness and lack of understanding of PPP value, high cost of economic and legal analysis, lack of simple and transparent legal solutions, skilled personnel, accessible information, complex and opaque selection of partners. As we see, the possibility of reducing or eliminating practically all the barriers is within the competence of the state, which assigns it the main responsibility for the implementation of the PPP as a factor for ensuring sustainable development.

Realizing the complexity of a phenomenon like a PPP, it is important to understand it from the standpoint of perception by the partners, each of which has and tries to defend their interests. Finding the PPP at the junction of the public and private interests makes it vulnerable to corruption, which O. Lukyanov regards as an archetype of the social degradation [23, p. 27], pointing out its historical roots and linking the growth of corruption with the decline of the national consciousness during the crisis and stressing the strong relationship between the archetype of power, the mechanisms for its legitimization and the archetype of corruption. We agree with his opinion that the archetypal nature of corruption is confirmed, in particular, by its persistent high level of perception in the underdeveloped societies. Like other manifestations of archetypes, modern corruption is complex. In the sphere of PPP the most corrupt and dangerous are the procedures for selection of a private partner that are often opaque and biased, the organization of public procurement, ensuring the quality monitoring of the provision of public services and compliance with the terms of the agreement, etc.

That is why, in our opinion, it is important to participate in the processes of PPP of the third sector, ensuring their openness and transparency. It is a broad process of abandoning the old stereotypes, changing the notion of the state as the sole subject of securing social and other rights of the citizens, forming new values, perceiving business as an equal partner of a public sector, acting on the basis of an agreement and having its own interests. Thus, the question of overcoming "collectively unconscious" in favour of conscious collective actions 
in support of sustainable development is being actualized. One of the ways of implementing this was the initiative of the UN Economic Commission for Europe to improve the mechanisms of public-private partnership known as People-first PPP [24], whose main criteria are directly increasing the access to basic services and reducing the social inequality and injustice; increase of economic efficiency; possibility of replication and further development of projects; the most complete involvement of all the interested parties.

Conclusions. Thus, the archetypal analysis of PPP as one of the factors contributing to sustainable development suggests the need for its perception as a complex phenomenon that in the broad sense means cooperation between the public sector, business and civil society, and in the narrow sense is interpreted as agreements, projects between the public and private sectors in the sphere of realization of the public interests. In conducting an archetypal evaluation of the PPP, it is important to concentrate not only on clarifying the peculiarities of the national character and mentality, but also on such important issues as the level and peculiarities of the formation of the civil society, its influence on reforms, innovations, corruption, barriers, etc. From the point of view of post-communist transformation, it is important to take into account the growing role of the civil society and the need to apply the principles of a new public administration, first of all, in terms of enhancing the role of the public and business in solving the public affairs.

An assessment of the impact of PPP on sustainable development can be car- ried out in a much wider context, in view of changing the mentality of the population, its relation to the role and tasks of the state and business, the provisions on the social functions of the business and relations with the civil society, etc. Perspective is the evaluation of PPP from the standpoint of concepts such as "stereotypes", "values", "interests", "motivation", "innovation", "social conformism", and "anomie", etc. The understanding of the relationship between the public and private sectors and civil society and the underlying foundations of transformational change will be needed.

\section{REFERENCES}

1. Simak S. V. (2016). Instytutsiinyi rozvytok publichno-pryvatnoho partnerstva: teoriia, metodolohiia, mekhanizmy derzhavnoho upravlinnia [Institutional Development of PublicPrivate Partnership: Theory, Methodology, Mechanisms of Public Administration]. Kyiv: AMU [in Ukrainian].

2. Tyshchenko V. F., Ostapenko V. M. (2016). Finansovyi potentsial publichno-pryvatnoho partnerstva: svitovyi dosvid ta perspektyvy realizatsii v Ukraini [Financial potential of public-private partnership: world experience and perspectives of realization in Ukraine]. Kharkiv: KhNEU im. S. Kuznetsia [in Ukrainian].

3. Melnyk A. F., Pidhaiets S. V. (2017). Derzhavno-pryvatne partnerstvo v systemi instytutiv natsionalnoi ekonomiky: mekhanizmy rozvytku [Public-private partnership in the system of institutes of the national economy: mechanisms of development]. Ternopil: TNEU [in Ukrainian].

4. Husiev V. O. (2015). Publichno-pryvatne partnerstvo yak mekhanizm realizatsii "Stratehii staloho rozvytku 
“Ukraina 2020” [Public-Private Partnership as a Mechanism for Implementation of "The Strategy of Sustainable Development "Ukraine 2020"]. Naukovi zapysky Instytutu zakonodavstva Verkhovnoi Rady Ukrainy - Scientific Notes of the Institute of Legislation of the Verkhovna Rada of Ukraine, 4, 67-73 [in Ukrainian].

5. Zhukovska A. Yu. (2017). Derzhavnopryvatne partnerstvo v sotsialnii sferi: zarubizhnyi dosvid ta perspektyvy zaprovadzhennia v Ukraini [Public-Private Partnership in the Social Sphere: Foreign Experience and Perspectives of Implementation in Ukraine]. Visnyk Ternopilskoho natsionalnoho ekonomichnoho universytetu - Bulletin of the Ternopil National Economic University, 3, 21-37 [in Ukrainian].

6. Ilchenko N. (2014). Synerhiia mizhsektornoho partnerstva v sotsialno-ekonomichnomu rozvytku hromady [Synergy of the cross-sectoral partnership in the socio-economic development of the community]. Zbirnyk naukovykh prats Cherkaskoho derzhavnohotekhnolohichnoho universytetu. Seriia: Ekonomichni nauky - Collection of scientific works of Cherkasy Statetechnological University. Series: Economic Sciences, 37 (2), 33-42 [in Ukrainian].

7. Lavrentii D. S. (2018). Katehoryzatsiia publichno-pryvatnoho partnerstva $\mathrm{v}$ poniatiinomu prostori sotsialnoi derzhavy [The categorization of publicprivate partnership in the conceptual space of a social state]. Publichne uriaduvannia - Public administration, 3 (13), 81-93 [in Ukrainian].

8. Maistro S. V. (2016). Derzhavnopryvatne partnerstvo yak instrument zabezpechennia staloho sotsialno-ekonomichnoho rozvytku rehionu [Stateprivate partnership as an instrument for ensuring sustainable socio-economic development of the region]. Visnyk Natsionalnoho universytetu tsyvilnoho zakhystu Ukrainy. Seriia: Derzhavne upravlinnia - Bulletin of the National University of Civil Protection of Ukraine. Series: Public Administration, 2, 243-249 [in Ukrainian].

9. Makara O. V. (2014). Derzhavnopryvatne partnerstvo $\mathrm{v}$ konteksti sotsialno oriientovanoho rozvytku krainy [Public-private partnership in the context of socially oriented country development]. Naukovyi visnyk NLTU Ukrainy - Scientific herald of NLTU of Ukraine, 24.1, 366-371 [in Ukrainian].

10. Kulchii I. M. (2017). Publichno-pryvatne partnerstvo yak sposib zabezpechennia staloho rozvytku silskykh terytorii [Public-Private Partnership as a Way to Ensure Sustainable Development of Rural Areas]. Problemy zakonnosti - Problems of legality, 138, 99-108 [in Ukrainian].

11. Pomohaibo B. V. (2016). Vektory udoskonalennia mekhanizmu realizatsii derzhavno-pryvatnoho partnerstva u konteksti zabezpechennia staloho rozvytku [Vectors of Improvement of the Mechanism for Realization of PublicPrivate Partnership in the Context of Sustainable Development]. Derzhavne upravlinnia: udoskonalennia ta rozvytok - State Administration: Improvement and Development, 9. Retrieved from http://nbuv.gov.ua/UJRN/ Duur_2016_9_14 [in Ukrainian].

12. PPP - dziedziny, korzysci, bariery oczami przedstawicieli sektora publicznego i prywatnego (2007-2011). (2011). Katowice. Retrieved from https://www.ppp.gov.pl/Aktualnosci/Documents/Raport PPPORTAL_031111.pdf [in Polish].

13. Materialy Mizhnarodnoi konferentsii "Vprovadzhennia derzhavno-pryvatnykh partnerstv, spriamovanykh na potreby liudei: krashchi mizhnarodni praktyky ta rekomendatsii dlia Ukrainy i krain-susidiv" [Materials of the Inter- 
national Conference "Implementation of public-private partnerships aimed at people's needs: best international practices and recommendations for Ukraine and its neighbors"]. (2018). www.me.gov.ua. Retrieved from http://www.me.gov.ua/Documents/ Detail? lang $=$ uk-UA\&id=ed00a2ba480a-4979-84eb-d610a0827a8c\&title $=$ ZagalniiOgliad [in Ukrainian].

14. Pattberg P., Biermann F., Chan S., Mert A. (Eds.). (2013). Public-private partnership for sustainable development: emergence, influence and legitimacy. Cheltenham: Edward Elgar [in English].

15. Hodge G., Greve C. (2017). On Public-Private Partnership Performance: A Contemporary Review. Public Works Management \& Policy, 22(1), 55-78 [in English].

16. Pinz A., Roudyani N., Thaler J. (2018). Public-private partnerships as instruments to achieve sustainability-related objectives: the state of the art and a research agenda. Public Management Review, 20(1), 1-22 [in English].

17. Lakhyzha M. I. (2009). Modernizatsiia publichnoi administratsii: teoretychni ta praktychni aspekty [Modernization of Public Administration: Theoretical and Practical Aspects]. Poltava: RVV PUSKU [in Ukrainian].

18. Tsili staloho rozvytku: Ukraina. Natsionalna dopovid 2017 [Sustainable Development Goals: Ukraine. National Report 2017]. (2017). www.un.org. ua. Retrieved from http://www. un.org.ua/images/SDGs_NationalReportUA_Web_1.pdf [in Ukrainian].

19. Procuring Infrastructure PublicPrivate Partnerships Report 2018. Assessing Government Capability to Prepare, Procure, and Manage PPPs. (n.d.). ppp.worldbank.org. Retrieved from https://ppp.worldbank.org/ public-private-partnership/library/ procuring-infrastructure-ppps-2018 [in English].
20. Private Participation in Infrastructure (PPI). Annual Report 2017 (2017). ppi.worldbank.org. Retrieved from http://ppi.worldbank.org/ /media/ GIAWB/PPI/Documents/GlobalNotes/PPI_2017_AnnualReport.pdf [in English].

21. Balakirieva O. M. (Eds.). (2015). Neekonomichni priorytety modernizatsii $\mathrm{v}$ Ukraini $\mathrm{z}$ urakhuvanniam intehratsiinoho dosvidu krain Tsentralno-Skhidnoi Yevropy: naukova dopovid [Non-economic priorities of modernization in Ukraine taking into account the integration experience of the countries of Central and Eastern Europe: scientific report]. Kyiv: NAN Ukrainy, DU "In-t ekon. ta prohnozuv. NAN Ukrainy" [in Ukrainian].

22. Tkaczuk M. (2008). Partnerstwo publiczno-społeczne jako etapewolucji podmiotów polityki społecznej w Polsce. Annales Universitatis Mariae Curie-Skłodowska. Sectio H. - Oeconomia, 42, 321-330 [in Polish].

23. Lukianov O. P. (2013). Koruptsiia yak arkhetyp derzhavnoho upravlinnia [Corruption as an Archetype of Public Administration]. Publichne upravlinnia: teoriia ta praktyka. - Public Administration: Theory and Practice, 2, 25-32 [in Ukrainian].

24. People-first PPPs. UNECE. (n.d.). www.uneceppp-icoe.org. Retrieved from https://www.uneceppp-icoe.org/ people-first-ppps/ [in English].

\section{СПИСОК ВИКОРИСТАНИХ ДЖЕРЕЛ}

1. Сімак $C$. В. Інституційний розвиток публічно-приватного партнерства: теорія, методологія, механізми державного управління : монографія / С. В. Сімак ; Акад. муніцип. упр. К. : АМУ, 2016. - 388 c.

2. Тищенко В. Ф. Фінансовий потенціал публічно-приватного партнерства: світовий досвід та перспективи 
реалізації в Україні : монографія / В. Ф. Тищенко, В. М. Остапенко. - Х.: ХНЕУ ім. С. Кузнеця, 2016. - 223 c.

3. Мельник А. Ф. Державно-приватне партнерство в системі інститутів національної економіки: механізми розвитку : монографія / А. Ф. Мельник, С. В. Підгаєць. - Тернопіль : THEУ, 2017. - 278 c.

4. Гусєв B. O. Публічно-приватне партнерство як механізм реалізації "Стратегії сталого розвитку "Україна 2020” / В. О. Гусєв // Наукові записки Ін-ту законодавства Верховної Ради України. - 2015. № 4. - С. 67-73.

5. Жуковська А. Ю. Державно-приватне партнерство в соціальній сфері: зарубіжний досвід та перспективи запровадження в Україні / А. Ю. Жуковська // Вісн. Тернопільського нац. економічного ун-ту. - 2017. № 3. - С. 21-37.

6. Ільченко Н. Синергія міжсекторного партнерства в соціально-економічному розвитку громади / Н. Ільченко // Зб. наук. пр. Черкаського держ. технологічного ун-ту. Серія : Економічні науки. - 2014. - Вип. 37(2). С. 33-42.

7. Лаврентій Д. С. Категоризація публічно-приватного партнерства в понятійному просторі соціальної держави / Д. С. Лаврентій // Публічне урядування. - 2018. - № 3 (13). - C. 81-93.

8. Майстро С. В. Державно-приватне партнерство як інструмент забезпечення сталого соціально-економічного розвитку регіону / С. В. Майстро // Вісн. Нац. ун-ту цивільного захисту України. Серія : Державне управління. - 2016. - Вип. 2. C. 243-249.

9. Макара О. В. Державно-приватне партнерство в контексті соціально орієнтованого розвитку країни /
О. В. Макара // Наук. вісник НЛТУ України. - 2014. - Вип. 24.1. C. 366-371.

10. Кульчій I. M. Публічно-приватне партнерство як спосіб забезпечення сталого розвитку сільських територій / I. М. Кульчій // Проблеми законності. - 2017. - Вип. 138. C. 99-108.

11. Помогайбо Б. В. Вектори удосконалення механізму реалізації державно-приватного партнерства у контексті забезпечення сталого розвитку [Електронний ресурс] / Б. В. Помогайбо // Державне управління: удосконалення та розвиток. - 2016. - № 9. - Режим доступу: http://nbuv.gov.ua/UJRN/ Duur_2016_9_14

12. PPP - dzièdziny, korzysci, bariery oczami przedstawicieli sektora publicznego i prywatnego (2007-2011). Raport PPPortal.pl [Електронний ресурс]. - Katowice, 2011. - Режим доступу: https://www.ppp.gov.pl/Aktualnosci/Documents/Raport_PPPORTAL_031111.pdf

13. Матеріали Міжнародної конференції “Впровадження державно-приватних партнерств, спрямованих на потреби людей: кращі міжнародні практики та рекомендації для України і країн-сусідів”, 2018 [Електронний ресурс] / М-во економічного розвитку та торгівлі України. - Pежим доступу: http://www.me.gov. ua/Documents / Detail ?lang =ukUA\&id=ed00a2ba-480a-4979-84ebd610a0827a8c\&title=ZagalniiOgliad

14. Public-private partnership for sustainable development: emergence, influence and legitimacy / Edited by P. Pattberg, F. Biermann, S. Chan, A. Mert. - Cheltenham, UK : Edward Elgar, 2013. - 288 p.

15. Hodge G. On Public-Private Partnership Performance: A Contemporary Review / G. Hodge, C. Greve // Pub- 
lic Works Management \& Policy. 2017. - Vol. 22 (1). - P. 55-78.

16. Pinz A. Public-private partnerships as instruments to achieve sustainability-related objectives: the state of the art and a research agenda / A. Pinz, N. Roudyani, J. Thaler // Public Management Review. - 2018. Vol. 20. - Issue 1. - P. 1-22.

17. Лахижа М. I. Модернізація публічної адміністрації: теоретичні та практичні аспекти / М. І. Лахижа. Полтава : РВВ ПУСКУ, 2009. 289 c.

18. Цілі сталого розвитку: Україна. Національна доповідь 2017 [Електронний ресурс] / Організація Об’єднаних Націй в Україні. - Режим доступу: http://www.un.org.ua/images/ SDGs_NationalReportUA_Web_1. pdf

19. Procuring Infrastructure PublicPrivate Partnerships Report 2018. Assessing Government Capability to Prepare, Procure, and Manage PPPs [Електронний ресурс] / International Bank for Reconstruction and Development; The World Bank. Режим доступу: https://ppp.worldbank.org/public-private-partnership/ library/procuring-infrastructureppps-2018
20. Private Participation in Infrastructure (PPI). Annual Report 2017 [Електронний ресурс] / World Bank. - Режим доступу: http://ppi. worldbank.org/ / media/GIAWB/ PPI/Documents/Global-Notes/ PPI_2017_AnnualReport.pdf

21. Неекономічні пріоритети модернізації в Україні 3 урахуванням інтеграційного досвіду країн Центрально-Східної Свропи : наукова доповідь / за ред. канд. соціол. наук О. М. Балакірєвої ; НАН України, ДУ "Ін-т екон. та прогнозув. НАН України”. - Київ, 2015. - 162 с.

22. Tkaczuk M. Partnerstwo publicznospołeczne jako etap ewolucji podmiotów polityki społecznej w Polsce / M. Tkaczuk // Annales Universitatis Mariae Curie-Skłodowska. Sectio H. Oeconomia. - 2008. - Vol. 42. S. 321-330.

23. Лук'янов О. П. Корупція як архетип державного управління / О. П. Лук'янов // Публічне управління: теорія та практика. - 2013. Вип. 2. - С. 25-32.

24. People-first PPPs [Електронний pecypc] / UNECE. International PPP Center of Excellence. - Режим доступу: https://www.uneceppp-icoe. org/people-first-ppps/ 